\title{
Dog epididymis-specific mRNA encoding secretory glutathione peroxidase-like protein
}

\author{
A. Beiglböck, I. Pera, K. Ellerbrock and C. Kirchhoff* \\ IHF Institute for Hormone and Fertility Research, University of Hamburg, Grandweg 64, \\ D-22529 Hamburg, Germany
}

\begin{abstract}
A differential library screening procedure was used to clone a novel abundant and tissue-specific cDNA from the dog epididymis. It was tentatively named CE7 for dog epididymal gene product 7. By sequence similarity to homologous counterparts expressed in mice, rats, pigs, and macaque monkeys, it appears that the $1.5 \mathrm{~kb}$ dog epididymal mRNA encodes the secretory glutathione peroxidase-like protein, GPX5. This protein is very similar to the family of glutathione peroxidase enzymes, but does not contain selenocysteine. Northern blot and in situ hybridization analyses revealed that the mRNA encoding CE7/GPX5, like its species homologues, was restricted to the epididymis and transcribed by the epithelial cells in the proximal parts of the organ. While the CE7 CDNA probe cross-hybridized to epididymal mRNAs in most species included in this study, it failed to identify a human GPX5 counterpart. Northern blot analyses of epididymal RNA extracts from hemi-cryptorchid dogs suggested that testicular secretions, including androgen hormones, temperature effects, or both, were involved in the region-dependent modulation of mRNA encoding CE7 in the dog epididymis. The effect was most obvious in the caput region of the abdominal organ where the mRNA encoding CE7 was almost completely downregulated.
\end{abstract}

\section{Introduction}

Glutathione peroxidases (GPXs) catalyse the reduction of hydrogen peroxide and various organic hydroperoxides using reduced glutathione, and thereby protect cells and sensitive biomolecules such as DNA, proteins, and lipids from oxidative damage (for review see Roveri et al., 1994). The enzyme activity is mediated by a family of selenium-dependent isoenzymes of different substrate specificity and tissue distribution, comprising the classic cytosolic GSHPx-1 (GPXI), the gastro-intestinal GSHPx-GI (GPX2) which is also cytosolic, the extracellular GSHPX-P found in blood plasma (GPX3), and the phospholipid hydroperoxide glutathione peroxidase PHGPX (GPX4), which exists as cytosolic and mitochondrial forms. All enzymes contain one selenocysteine residue per subunit in their active sites. Their evolutionarily conserved gene transcripts encode the atypical amino acid by an in-frame UGA (opal) codon which normally functions as a termination signal.

The human GPX selenoproteins are all encoded by different genes located on different chromosomes (Chu, 1994), thus forming a family of related, but clearly distinct members. Recent reports of a unique secretory, androgen-dependent product in the epididymis of various mammals (mouse: Faure et al., 1991; Chyselinck et al., 1993; rat and monkey: Perry et al., 1992; boar: accession number D37916) add another member to

*Correspondence.

Received 21 July 1997. this gene family. It is very similar to the described family of glutathione peroxidase enzymes, but does not contain selenocysteine, or at least does not contain a selenocysteine-encoding UGA codon. This finding suggests that the epididymal product and the secretory GPX3 from blood plasma, albeit both being extracellular proteins, are representatives of different subgroups of this gene family (Perry et al., 1992). cDNA sequence analyses showed that, unlike other epididymal secretory proteins, the predicted glutathione peroxidase-like protein is evolutionarily well conserved.

The mouse epididymal secretory protein has been tentatively named GPX5 (Vernet et al., 1996, 1997), although it has not yet been proven unequivocally that the protein functions as a true glutathione peroxidase in vivo. GPX5 and its species homologues constitute a major protein of the caput epididymidis in all mammals investigated thus far. In mice, it has been shown to be synthesized by the epithelial cells of the epididymal duct and secreted into the lumen, where it binds to spermatozoa (Vernet et al., 1997). Its expression in the caput region is very sensitive to the depletion of androgens and other testicular factors after castration (Faure et al., 1991; Perry et al., 1992; Ghyselinck et al., 1993).

A related human epididymal gene product has not yet been found. Differential screening of human epididymal cDNA libraries, using methodology designed to clone major tissuespecifically expressed transcripts (Kirchhoff $e t$ al., 1990, 1991, 1993, 1994; Osterhoff $e t$ al., 1994, 1997) as well as screening with various GPX5-encoding CDNA probes from other species, failed to identify a human counterpart (data not shown). 
(a) tcgccgttgg ctacaggatc aaagcttga cagggtgtgt gtgagatc cc agcctcaaaa actacatcta cggactagtc atg act gca tgg tta ggg gcc

tcc tac gtt ttg cet att ctg cta gtc agc ttt gtg cag aca aat gcc 149 $\begin{array}{lllllllllllllllll}S & Y & V & L & P & I & L & L & V & S & F & V & Q & T & N & A & +2\end{array}$ $-1 \Uparrow+1$

aag cct gag aag aca aag atg gat tgc tat aaa gat gtg aaa gga acc 197 $\begin{array}{lllllllllllllllll}\mathrm{K} & \mathrm{P} & \mathrm{E} & \mathrm{K} & \mathrm{T} & \mathrm{K} & \mathrm{M} & \mathrm{D} & \mathrm{C} & \mathrm{Y} & \mathrm{K} & \mathrm{D} & \mathrm{V} & \mathrm{K} & \mathrm{G} & \mathrm{T} & +18\end{array}$ atc tat gaa tat gaa gcc ctc act ctc aat gga at gaa cgc att cag 245 $\begin{array}{lllllllllllllllll}I & \mathrm{Y} & \mathrm{E} & \mathrm{Y} & \mathrm{E} & \mathrm{A} & \mathrm{L} & \mathrm{T} & \mathrm{L} & \mathrm{N} & \mathrm{G} & \mathrm{N} & \mathrm{E} & \mathrm{R} & \mathrm{I} & \mathrm{Q} & +34\end{array}$

ttc aag cag tat $\mathrm{ccg} \operatorname{cgc}$ aag cat gtt ctt ttt gtc aat gtg gcc acc 293 $\begin{array}{lllllllllllllllll}\mathrm{F} & \mathrm{K} & \mathrm{Q} & \mathrm{Y} & \mathrm{P} & \mathrm{R} & \mathrm{K} & \mathrm{H} & \mathrm{V} & \mathrm{L} & \mathrm{F} & \mathrm{V} & \mathrm{N} & \mathrm{V} & \mathrm{A} & \mathrm{T} & +50\end{array}$

tat tgt ggt ctg aca gct cag tat cct gaa ctg aat tca ctt cag gag 341

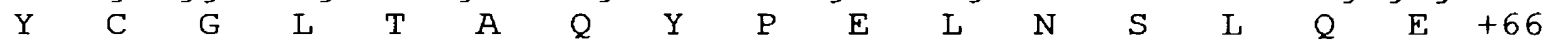
gag ctg aag cec ctt ggc ctg gtt gta ttg ggc ttt ccc tgc aac caa 389 $\begin{array}{lllllllllllllllll}E & \mathrm{~L} & \mathrm{~K} & \mathrm{P} & \mathrm{L} & \mathrm{G} & \mathrm{L} & \mathrm{V} & \mathrm{V} & \mathrm{L} & \mathrm{G} & \mathrm{F} & \mathrm{P} & \mathrm{C} & \mathrm{N} & \mathrm{Q} & +82\end{array}$

ttt ggg aag cag gga cca gga gag aac tca gag att ctt ccg ggc ctg 437 $\begin{array}{lllllllllllllllll} & \mathrm{G} & \mathrm{K} & \mathrm{Q} & \mathrm{G} & \mathrm{P} & \mathrm{G} & \mathrm{E} & \mathrm{N} & \mathrm{S} & \mathrm{E} & \mathrm{I} & \mathrm{L} & \mathrm{P} & \mathrm{G} & \mathrm{L} & +98\end{array}$

aag tac gtc cgg cca ggc aga ggc tat gtc cet aac ttc cag ctc ttt 485

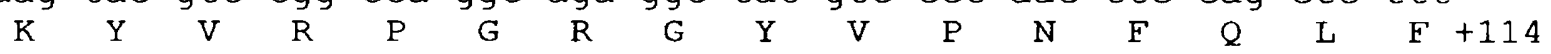

gag aaa ggg gat gtg aat ggt gaa aaa gaa cag aaa gtc ttc acc ttc 533 $\begin{array}{llllllllllllllll}\mathrm{E} & \mathrm{K} & \mathrm{G} & \mathrm{D} & \mathrm{V} & \mathrm{N} & \mathrm{G} & \mathrm{E} & \mathrm{K} & \mathrm{E} & \mathrm{Q} & \mathrm{K} & \mathrm{V} & \mathrm{F} & \mathrm{T} & \mathrm{F} \\ +130\end{array}$

ttg aag ctc tcc tgc cet cac ccc tca gag gtt cta ggc tcc ttc aga 581 $\begin{array}{lllllllllllllllll}\mathrm{L} & \mathrm{K} & \mathrm{L} & \mathrm{S} & \mathrm{C} & \mathrm{P} & \mathrm{H} & \mathrm{P} & \mathrm{S} & \mathrm{E} & \mathrm{V} & \mathrm{L} & \mathrm{G} & \mathrm{S} & \mathrm{F} & \mathrm{R}+146\end{array}$

cac atc tcc tgg gat cet gta aag gtc cac gat atc cgc tgg aac ttt 629 $\begin{array}{llllllllllllllll}\mathrm{H} & \mathrm{I} & \mathrm{S} & \mathrm{W} & \mathrm{D} & \mathrm{P} & \mathrm{V} & \mathrm{K} & \mathrm{V} & \mathrm{H} & \mathrm{D} & \mathrm{I} & \mathrm{R} & \mathbf{W} & \mathbf{N} & \mathrm{F}\end{array}$

gag aag ttc ctg gtg ggg cet gat ggg gtc cet gtc ctg cgc tgg ttc 677

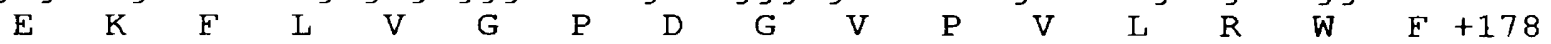

cac cgg act ccc atc agc act gtc aag gaa gac atc ctg gtc tac ctg 725 $\begin{array}{llllllllllllllll}H & R & T & P & I & S & T & V & K & E & D & I & L & V & Y & L \\ +194\end{array}$

aaa cag ctc aaa atg aaa tag gaaggcagga gcaaccctgc ttctcatcag aa 778 $\begin{array}{lllllllll}K & Q & L & K & M & K & * & +200\end{array}$ gacggttt taaaaaatt ccagatttca cgacattctt ctaaatggcc tgccettgac 836 caaagcatgc tgtaccgcca gagttcccac tctctaccaa gcagttatat attcagaa 894 ga ctactgctat ttctccttgc aagtccgtat gtggaagaag aacaaagaat ggaac 951 ctcta aatccttaga cctctaatat aaataattt aatcggtcct gtccatcaaa ga 1008 aatctag cgttccatga ggatggttca gtctgccaca acatcctgaa aaagaacgtt 1066 ccagacagaa tgttccccct tctctttcca ctcaaaagtg tagaaataac agtgggat 1124 gg tagccataca gccgagtttc caccttataa cacctgccct ccaccgtgac aaaca 1181 cgtat tgtcagtttc caagtcttt gagaccagtg gttcatccat gaaacttacc ct 1238 cccataca cacagtgtcc tgtcattctg gcttatgagc tctaaggtgg agtgagagca 1296 ggagactgcc ttgccaagga tagaaggaca tctccatggt agtggacccg gagcctct 1354 ct atcatttaga tcctacagaa acttccctgc tgtctgactt gtagtgcact caggt 1411 catga cacctggaca atgcatcctt tgaaggatgg gctttctctt gtccatccta ga 1468 ttcttcag cttcagaacc agctctgcat tgtctccaat aaaatgtttt ctacagc(a) 1523 
(b)

\begin{tabular}{|c|c|c|}
\hline Dog & MTAWLGASYVLP ILLVSFVQTNAKPEKTKMDCYKDVKGTIYEYEALTLNG & 50 \\
\hline Pig & MTVQLGAFYLFPLFMAGFVQTNSNLE- - RMDCYXDVTGTIYDYDAFTLNG & \\
\hline Monkey & MTTQLRVVHLLPLLLACFVQTS PKQETMKMDCHRDEKGTIYDYEAIALNK & \\
\hline Rat & MAIQLRVFYLVPLLLASYVQTTPRLEKMKMDCYKDVKGTIYNYEALSLNG & \\
\hline Mouse & MVTELRVFYLVPLLLASYVQTTPRPEKMKMDCYKDVKGTIYDYEALSLNG & \\
\hline Dog & NER IQFKQYPRKHVLFVNVATYCGLTAQYPELNSLQEELRPLGLVVLGFP & 100 \\
\hline Pig & NEH IQFKQYAGKHVLFVNVATYCGLTAQYPELNTLQEELRPFGLVVLGFP & \\
\hline Monkey & NEYVPFRQYVGKH ILFVNVATYCGLTAQYPELNALQEELKPYGLVVLGFP & \\
\hline Rat & KER I PFKQYAGRHVLFVNVATYCGLT IQYPELNALQDDLRQFGLVILGFP & \\
\hline Mouse & KED I PFKQYRGRHVLFVNVATYCGLT IQYPELNALQEDLK PFGLV I LGFP & \\
\hline Dog & CNQFGKQGPGENSEILPGLRYVRPGRGYVPNFQLFERGDVNGEKEQKVFT & 150 \\
\hline Pig & CNQFGKQEPGENSEILLGLKYVRPGGGYVPNFQLFERGDVNGEKEQKVFT & \\
\hline Monkey & CNQFGKQEPGDNKEILPGLKYVRPGGGFVPNFQLFEKGDVNGEKEQKVFS & \\
\hline Rat & CNQFGKQEPGDNTEILPGLKYVRPGKGFLPNFQLFARGDVNGEKEQE IFT & \\
\hline Mouse & CNEFGKQEPGDNLEILPGLKYVRPGKGFLPNFQLFAKGDVNGENEQKIFT & \\
\hline Dog & FLRLSCPHPSEVLGSFRH I SWDPVKVHDIRWNFEKFLVGPDGVPVLRWFH & 200 \\
\hline Pig & FLKHSCPHP SELIGS IGY I SWEP IRVHDIRWNFERFLVGPDGVPVMRWVH & \\
\hline Monkey & FLRHSCPHPSEILGTFKS ISWDPVKVHDIRWNFEKFLVGPDG I PVMRWSH & \\
\hline Rat & FLKRSCPHPSETVVTSKHTFWEP IKVHDIRWNFEKFLVGPNGVPVMRWFH & \\
\hline Mouse & FLRRSCPHPSETVVMSKHTFWEP I KVHDIRWNFERFLVGPDGVPVMRWFH & \\
\hline Dog & RTPISTVKEDILVYLKQLKMK & 221 \\
\hline Pig & ETPISTVKSDILAYLKQFKTE & \\
\hline Monkey & RATVSSVRTDILAYLKQFKTK & \\
\hline Rat & QAPVSTVKSDILAYLNQFRTI & \\
\hline Mouse & QAPVSTVKSDIMAYLSHFKTI & \\
\hline \multicolumn{3}{|c|}{$\begin{array}{l}\text { Fig. 1. Nucleotide and predicted peptide sequence of the 'near full-length' cDNA encoding CE7 from dog } \\
\text { epididymis. (a) CDNA sequence and amino acid sequence of CE7 as translated from open reading frame. Arrow } \\
\text { ( } \uparrow \text { ) points to putative site for signal peptidase cleavage. Asterisk }(*) \text { marks tag stop codon. Polyadenylation } \\
\text { signals are underlined. (b) Alignment of putative dog CE7 peptide sequence (dog) with the closely related } \\
\text { sequences from other mammals (pig: EMBL accession number D37916; monkey: X62403; rat: X62404; mouse: } \\
\text { X53780). Amino acids that are identical between species are in bold. }\end{array}$} \\
\hline
\end{tabular}

Previous studies had already recommended the dog as a suitable model for the human epididymis, as it expresses a number of closely related gene products in a similar spatial pattern (Ellerbrock et al., 1994; Pera et al., 1994, 1996). Therefore, a similar differential screening procedure was applied to a dog epididymal cDNA library. This study describes the successful cloning of a novel, very abundant cDNA of the dog epididymis, tentatively named CE7 for dog epididymal gene product 7 . Its sequence similarity and expression pattern suggested that it encodes the dog homologue of GPX5. Northern analysis showed that it cross-hybridized with epididymal mRNAs of most mammalian species, but not those of humans.

\section{Materials and Methods}

Tissues

Dog testes and epididymides were obtained from local veterinary practices, where dogs were being castrated for behavioural disturbances. Tissues from sexually mature animals were removed rapidly, the epididymides cleaned of irrelevant tissue and snap-frozen in liquid nitrogen, either as entire organs or separated according to gross morphology into caput, corpus and cauda regions. In addition, scrotal and abdominal epididymides from two hemi-cryptorchid animals were included in the analysis. Preliminary studies involving tissues from a wide variety of breeds and mongrels showed that epididymal tissue can probably be taken from any breed of dog with the expectation of comparable results (Ellerbrock et al., 1994). Nevertheless, for the present study, preference was given to medium-sized, outbred (mongrel) dogs. Epididymal tissues from bull, boar, and stallion were obtained at operation (courtesy of F. Uhlenbruck, IHF, Hamburg). Epididymal tissue from a male marmoset (Callithrix jacchus) was kindly provided by A. Einspanier, Deutsches Primaten-Zentrum, Göttingen. Rodent epididymides were from freshly killed laboratory animals. Human epididymides and testes were obtained from local hospitals where patients with prostatic carcinoma were undergoing orchidectomy. The requirements of the Helsinki Declaration were observed in all cases. 


\section{Differential screening of a dog epididymal cDNA library}

A dog epididymal cDNA library that had been constructed in the bacteriophage vector Lambda UniZAP-XR (Ellerbrock et al., 1994) was screened using a differential hybridization strategy essentially as described by Kirchhoff et al. (1990). Approximately 10000 independent cDNA clones were plated at low density (500 plaque forming units per plate) and screened by a multistep differential procedure, using ${ }^{32}$ P-radiolabelled single-stranded cDNA pools from dog liver, testis and lung as negative controls. Epididymis-positive plaques were isolated and purified by successive dilution, and the inserted cDNA sequence recovered by excision in vivo as described by Ellerbrock et al. (1994). The resulting recombinant plasmid DNAs were amplified and purified according to standard procedures, and subjected to DNA sequence analysis.

\section{RNA preparation, hybridization probes and northern blot analysis}

RNA from various tissues was extracted into $15-20$ volumes of chaotropic solution as described by Pera et al. (1996). RNA (5-20 $\mu \mathrm{g}$ per lane, depending on the experiment) was separated by denaturing agarose gel electrophoresis and transferred to Hybond N (Amersham-Buchler, Braunschweig) nylon membranes as described by Kirchhoff et al. (1990). Equal RNA loading was ascertained by ethidium bromide staining of gels before blotting. In some experiments involving the analysis of human epididymal RNA, poly(A)-containing RNA was enriched by oligo(dT)-affinity chromatography (Kirchhoff et al., 1990). ${ }^{32}$ P-labelling of a PCR-cloned 650-bp CE7 cDNA probe was performed by random primer labelling of an isolated insert comprising the open reading frame (Fig. 1). Radioactive CEI-, CE4-, and CE5-probes were prepared by ${ }^{32} \mathrm{P}$-random primer labelling of cDNA fragments as described by Ellerbrock $e t$ al. (1994). Probe hybridization to northern blots, washing and dehybridization were performed according to standard procedures as described by Kirchhoff et al. (1990).

\section{In situ transcript hybridization}

Epididymides from two medium-sized dogs were fixed in Bouin's solution for $6 \mathrm{~h}$, washed in $70 \%$ ethanol, and embedded in paraffin wax. Sections $(10 \mu \mathrm{m})$ were prepared and subjected to a non-radioactive hybridization procedure essentially as described by Maguire et al. (1993), using a cRNA probe labelled by in vitro transcription of the 650-bp CE7 cDNA fragment comprising the open reading frame (Fig. 1) in the presence of digoxigenin-UTP (Boehringer Mannheim, Mannheim). Alkaline phosphatase-conjugated anti-digoxigenin antibody (Boehringer Mannheim) and detection reactions were performed following the instructions of the supplier. Negative controls were performed in parallel on adjacent sections, using the corresponding digoxigenin-labelled sense-strand cRNA encoding CE7. Sections were analysed by brightfield microscopy without counterstaining.

\section{Results}

Sequence homology of $C D N A$ encoding CE7 to glutathione peroxidase-like gene products

Differential screening of a dog epididymal cDNA library (Ellerbrock et al., 1994) was performed using complex single- stranded, ${ }^{32}$ P-labelled cDNA pools from dog epididymis as a positive probe, and from liver, testis and lung cDNAs as negative probes. Out of the approximately 10000 independent cDNA clones included in the primary screening procedure, seven epididymis-positive clones were isolated, constituting a family of overlapping and colinear sequences. The cDNA clone family represented a novel dog epididymal gene product, tentatively named CE7 for dog epididymal gene product 7 . Rescreening of approximately 100000 clones of the dog epididymal cDNA library showed that the cDNA encoding CE7 occurred at an estimated frequency of approximately $0.3 \%$.

Two CE7 cDNA clones containing the longest inserts were sequenced in both directions, and their sequences were compiled by DNASTAR software to obtain a $1523 \mathrm{bp}$ "near full-length' cDNA sequence (Fig. 1). The cDNA consisted of 80 nucleotides of $5^{\prime}$ untranslated region (UTR), followed by an open reading frame (ORF) and a long $3^{\prime}$ UTR followed by a poly (A) tail. Database searches revealed high homology ( $>80 \%$ nucleotide identity) to the epididymis-specific secretory glutathione-peroxidase-like gene products of several mammalian species (pig: EMBL accession number D 37916; rat and macaque monkey: Perry et al., 1992; mouse: Ghyselinck et al., 1991, 1993). An ATG start codon at nucleotide 81 was embedded in a typical Kozak consensus sequence and was proposed by analogy with the reported epididymal secretory sequences of cDNA encoding GPX. After this putative start ATG, the cDNA sequence harbours a 663-nucleotide ORF predicting a protein of 221 amino acids, and a $780 \mathrm{bp} 3^{\prime}$ UTR (Fig. 1a). The first in-frame TGA codon at position 774 was suggested to function as stop codon by analogy to the reported sequences. The $3^{\prime}$ untranslated region contained two AATAAA motifs at position 978 and 1504 . The latter seemed to function as the primary polyadenylation signal (compare with Fig. 2). A shorter RNA species of approximately $1.0 \mathrm{~kb}$ was occasionally observed during northern analyses (see Fig. 2). It was not investigated whether it resulted from the use of the first AATAAA motif as a polyadenylation signal or rather represented a specific degradation product of mRNA encoding CE7.

Amino acid alignments (Fig. 1b) suggested that CE7 indeed represented the dog homologue of the secretory glutathione peroxidase-like product, GPX5. The deduced CE7 protein was 221 amino acids in length with a 21-amino acid N-terminal hydrophobic region that fits predictions for a cleavable signal peptide. The predicted CE7 protein sequence was nearly $80 \%$ identical to the pig homologue, $77 \%$ to the monkey homologue, and 74 and $73 \%$ to mouse and rat homologues, respectively. Like the other mammalian GPX5 species homologues, the dog CE7/GPX5 product did not encode a selenocysteine. Nevertheless, it showed approximately $68 \%$ amino acid identity to the human plasma GPX3 (EMBL accession number P22352).

\section{Tissue distribution and in situ localization of $m R N A$ encoding dog} CE7

Northern analyses were performed, including total RNA extracts from various dog tissues, to assess the epididymal abundance of mRNA encoding CE7 relative to other organs 

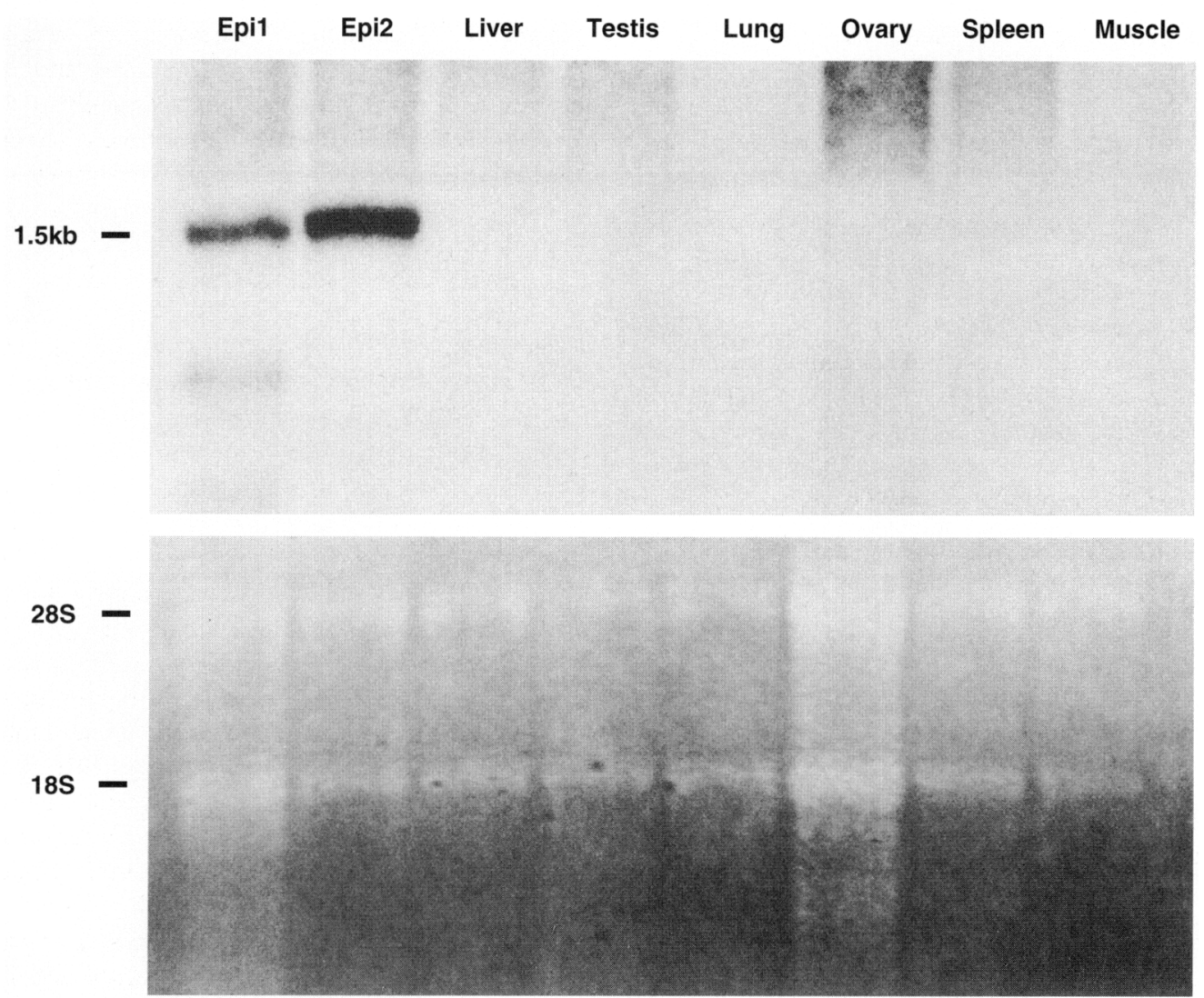

Fig. 2. Northern analysis of tissue distribution of mRNA encoding CE7/GPX5 in the dog. $A{ }^{32} \mathrm{P}$-labelled $650 \mathrm{bp}$ CE7 cDNA fragment was hybridized to a blot containing approximately $20 \mu \mathrm{g}$ of total RNA per lane (upper panel) as extracted from enriched dog epididymal epithelial cells (EpiI) and from a set of dog tissues, including epididymis (Epi2), liver, testis, lung, ovary, spleen and muscle. The integrity and transfer of ribosomal RNA (28S and 18S) was checked by ethidium bromide staining of the blot (bottom panel, showing overloading of ovary RNA).

(Fig. 2). High stringency hybridization using a ${ }^{32}$ P-labelled CE7 CDNA fragment revealed that the mRNA encoding CE7 was present in the epididymis, but not in other dog tissues. One strong signal was observed corresponding to an approximately $1.5 \mathrm{~kb}$ mRNA species (Fig. 2), corroborating the assumption that the 1523 basepair cDNA sequence (Fig. Ia) was 'full-length'. Thus, the dog mRNA encoding CE7/GPX5 seemed to be of approximately the same length as reported for the mouse (1470 bp. Ghyselinck et al., 1993) and boar (1450 bp) cDNAs encoding GPX5, but was significantly shorter than the approximately $1.9 \mathrm{~kb}$ mRNAs of rats and monkeys (Perry et al., 1992).

Dog epididymides were dissected and enriched for epithelial cells before RNA extraction as described by Pera et al. (1996) to determine whether the mRNA encoding CE7 was expressed by the epithelial cells lining the epididymal duct. Epitheliumenriched RNA extracts were positive for the same approximately $1.5 \mathrm{~kb}$-message as were whole tissue extracts of the dog epididymis (Fig. 2). Localization of CE7 transcripts in the epididymal epithelium was achieved by non-radioactive in situ hybridization, using a digoxigenin-labeiled CE7-antisense cRNA as a positive and the corresponding sense cRNA as a negative hybridization probe (Fig. $3 a-f)$. With the antisense probe, strong epithelial staining was observed throughout the proximal parts of the dog epididymis (Fig. 3a,c,e). The specificity of this reaction was shown by a comparison with adjacent sections through the same dog tissue that had been hybridized with the labelled sense riboprobe (Fig. $3 \mathrm{~b}, \mathrm{~d}, \mathrm{f}$ ). In some areas of the corpus epididymidis, a characteristic 'checkerboard' pattern of expression was observed (Fig. 3c, see arrows). Within the same cross-section, some epithelial cells exhibited strong labelling whereas directly adjacent cells displayed significantly lower or even no expression (Fig. 3c,e).

\section{Regionalized expression pattern and modulation of epididymal expression of mRNA encoding CE7}

Northern blot analyses were performed including equal amounts of total RNA extracts from the various regions of the dog epididymis and deferent duct. mRNA encoding CE7/GPX5 was very abundant in the caput region and, in fact, this part of the epididymis contained the vast majority of this mRNA (Fig. 4). The amount of mRNA encoding CE7 markedly decreased in the corpus epididymidis, and was barely detectable in the cauda epididymidis and the deferent duct under the same conditions. Several other dog epididymal cDNAs, encoding CE1, CE4, and CE5/CD52 (Ellerbrock et al, 1994), each 

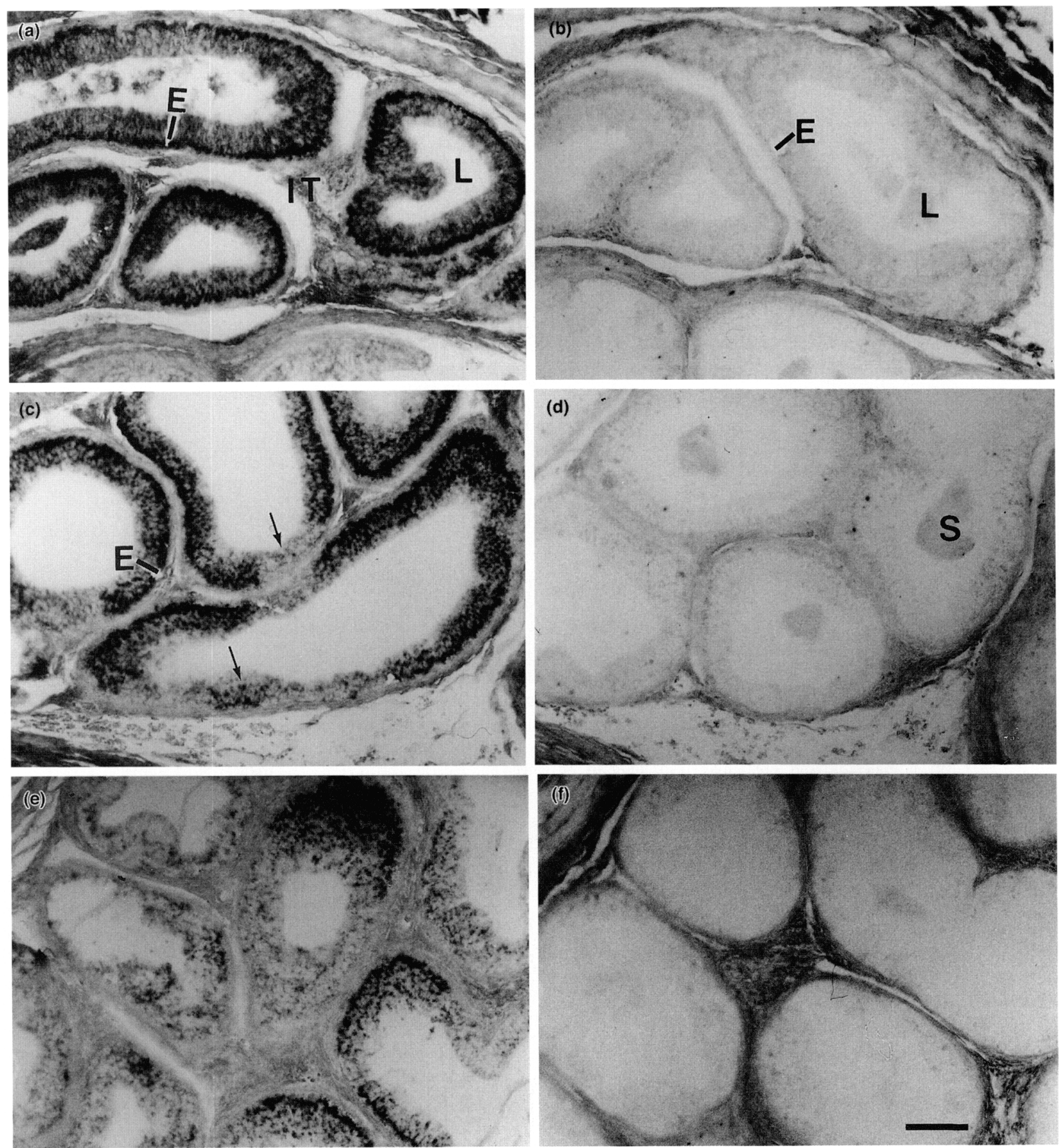

Fig. 3. Localization of CE7 transcripts in cross-sections through the proximal dog epididymis using non-radioactive in situ transcript hybridization. (a,c,e) Sections hybridized with a digoxigenin-labelled antisense-CE7 cRNA. (b,d,f) Adjacent sections hybridized with the corresponding sense-CE7 cRNA. Hybrids detected by an immunostaining procedure using anti-digoxigenin antibodies were visualized by standard brightfield microscopy. E: epididymal epithelium; IT: interstitial tissue; L: lumen of epididymal duct; S: spermatozoa. Arrows point to 'checkerboard' labelling of epididymal epithelium. Scale bar represents $54 \mu \mathrm{m}$.

showing a different, regionalized pattern of expression (Pera et al., 1994, 1996), were included as controls and used in the analysis of the same northern blot (Fig. 4).

In an attempt to define factors that regulate the expression of CE7 in the dog epididymis, the epididymides of two naturally occuring hemi-cryptorchid animals were investigated.
In these adult animals, one testis plus epididymis had remained in the abdomen during their entire life. The corresponding contralateral scrotal epididymides of each animal served as a control. Total RNA extracts were obtained from either whole scrotal and abdominal organs ( $\operatorname{dog} 1$ ) or from scrotal and abdominal organs as separated into caput, corpus, cauda 
Dog 1

Dog 2

ab sc abdominal scrotal

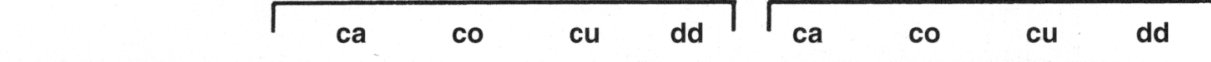

(a)

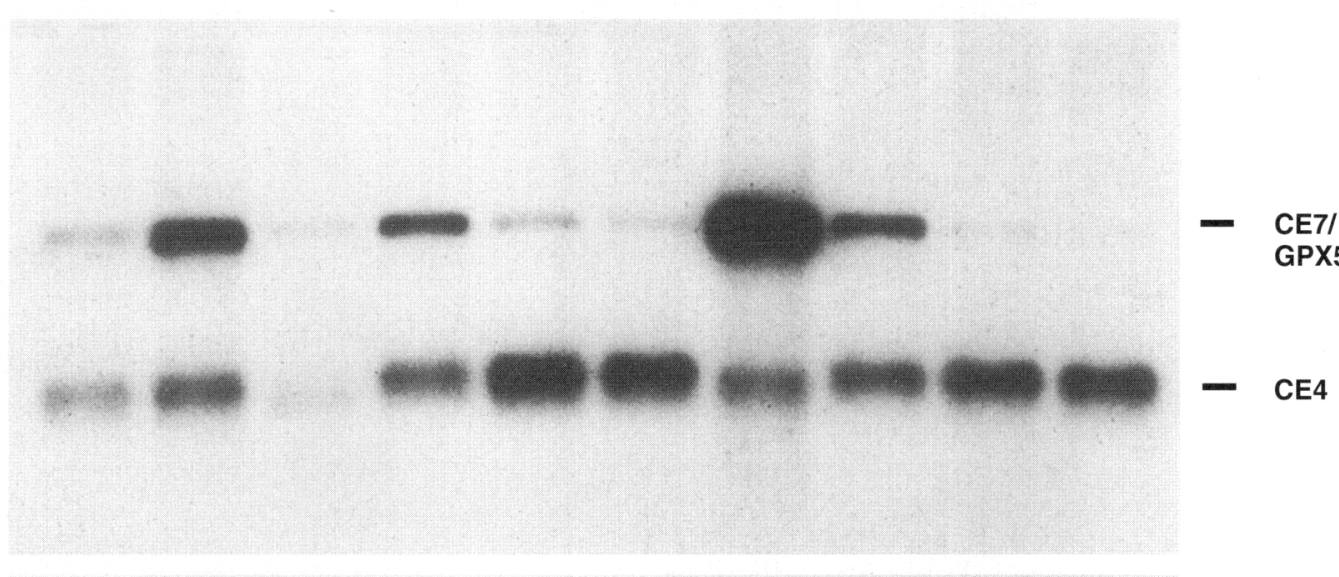

(b)

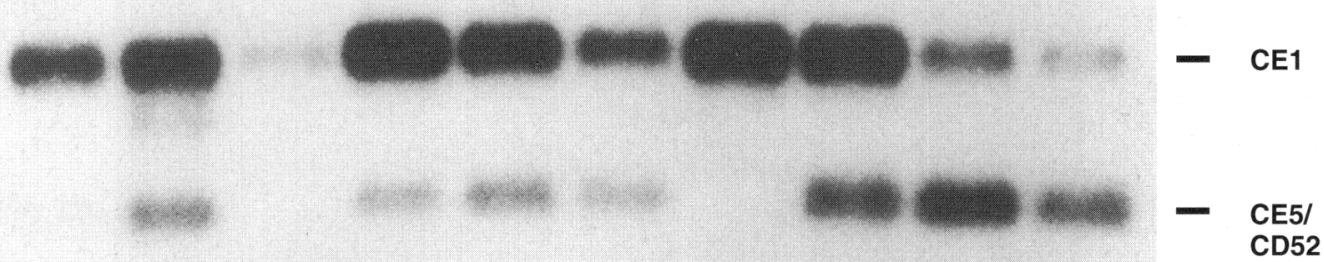

(c)

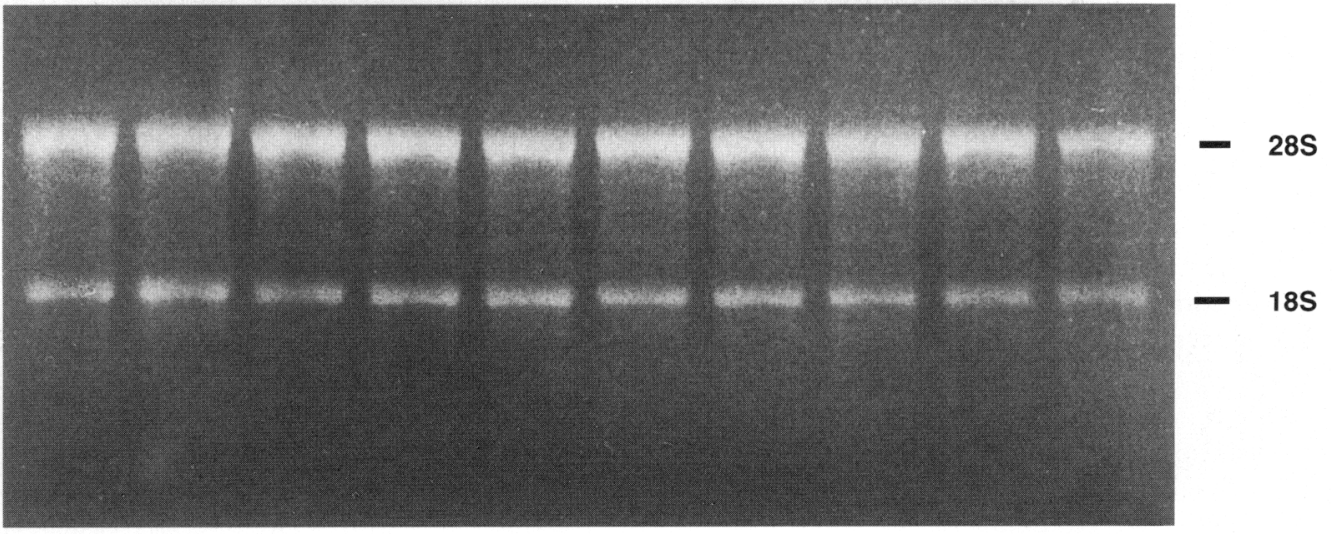

Fig. 4. Comparison of abundance of mRNA in abdominal and scrotal epididymides of two hemi-cryptorchid dogs. Lanes 1 and 2: RNA extracts from whole abdominal (ab) and corresponding scrotal (sc) organ; lanes 3-6: RNA extracts from abdominal organ; lanes 7-10: RNA extracts from scrotal organ after separation into caput (ca), corpus (co), cauda (cu), and proximal deferent duct (dd). ${ }^{32}$ P-labelled cDNA fragments encoding CE7/GPX5 and CE4 were hybridized to the northern blot (a). After dehybridization, the same blot was re-hybridized with ${ }^{32}$ P-labelled CE1 and CE5/CD52 cDNA fragments (b). Equal loading ( $5 \mu \mathrm{g}$ per lane) and integrity of ribosomal RNA ( $28 \mathrm{~S}$ and $18 \mathrm{~S}$ ) were ascertained by ethidium bromide staining of the gel before blotting $(c)$.

and vas regions ( $\operatorname{dog} 2)$, run on the same northern gel and hybridized as described.

The abdominal location markedly reduced the concentration of mRNA encoding CE7 as compared with scrotal concen- tration (Fig. 4). However, this reduction was restricted to the caput region of the abdominally located organ. In the distal segments, concentrations of mRNA encoding CE7 were barely affected. A similar, albeit less marked, reduction in the 
(a)

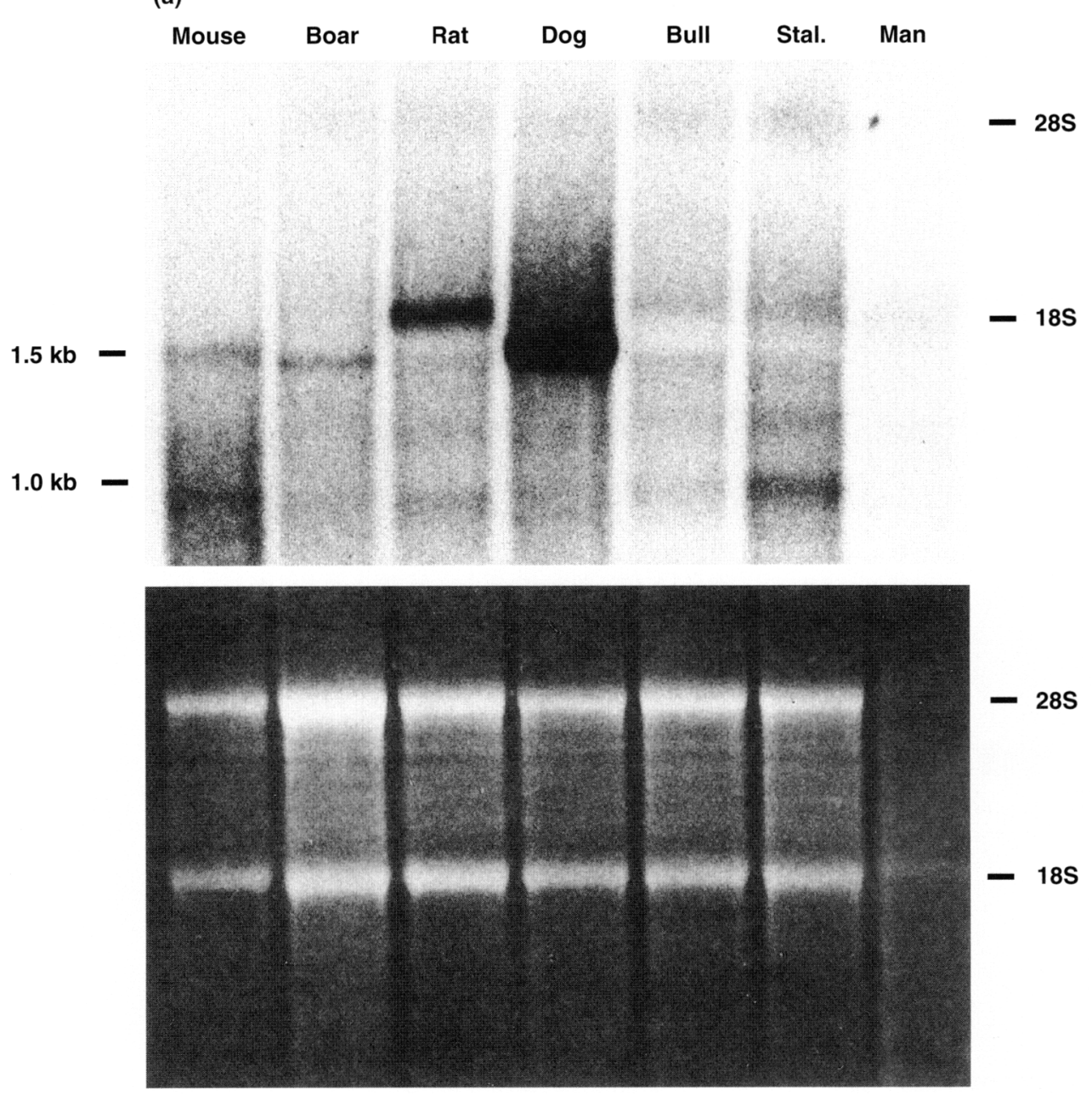

Fig. 5a. Legend on facing page.

abdominal versus scrotal epididymis was observed for two other secretory protein-encoding mRNAs, namely the mRNAs encoding CEI and CE4 (Ellerbrock et al., 1994). Their downregulation in the abdominal organs was also confined to the caput region (Fig. 4). Only in the case of the mRNA encoding CE5/CD52, which is not expressed in the dog caput epididymidis, was a reduction of mRNA concentrations observed in the distal parts of the organ (compare with Pera et al, 1996).

\section{Interspecies conservation of GPX5 expression among mammals}

Zoo blots containing total RNA extracts from epididymal tissue of seven different mammal species, including humans, were hybridized under low-stringency conditions. Hybridization signals at apparent molecular weights similar to reports in the literature were obtained with mouse, rat, and boar RNA extracts (Fig. 5a). No clear signals in this size range were observed with epididymal RNA from bulls, stallions, and men, the last one showing signs of degradation. Bull and stallion epididymal RNA nevertheless showed signals at reduced size
(Fig. 5a). Since cross-hybridization with mRNAs encoding other members of the GPX gene family could not be excluded under the low stringency conditions used, their identity remains unclear.

In another experiment to enrich samples for mRNA encoding GPX5, caput epididymal RNA extracts were prepared from the epididymides of various mammalian species, including humans (Fig. 5b). In addition to the already identified species homologues, a putative bovine GPX5-homologous mRNA was observed at approximately $2 \mathrm{~kb}$. However, marmoset and human epididymal RNA samples, including human caputenriched and poly $(A)$-enriched RNA samples, were again negative. A ${ }^{32}$ P-labelled HE2 $\mathrm{CDNA}$ probe encoding an mRNA specific to the human caput epididymidis (Osterhoff et al., 1994) was included as a positive control (Fig. 5b).

\section{Discussion}

The CDNA encoding CE7 described in this study was concluded to encode the dog homologue of the secretory epididymal GPX5 for the following reasons: (1) it shared extensive 
(b)
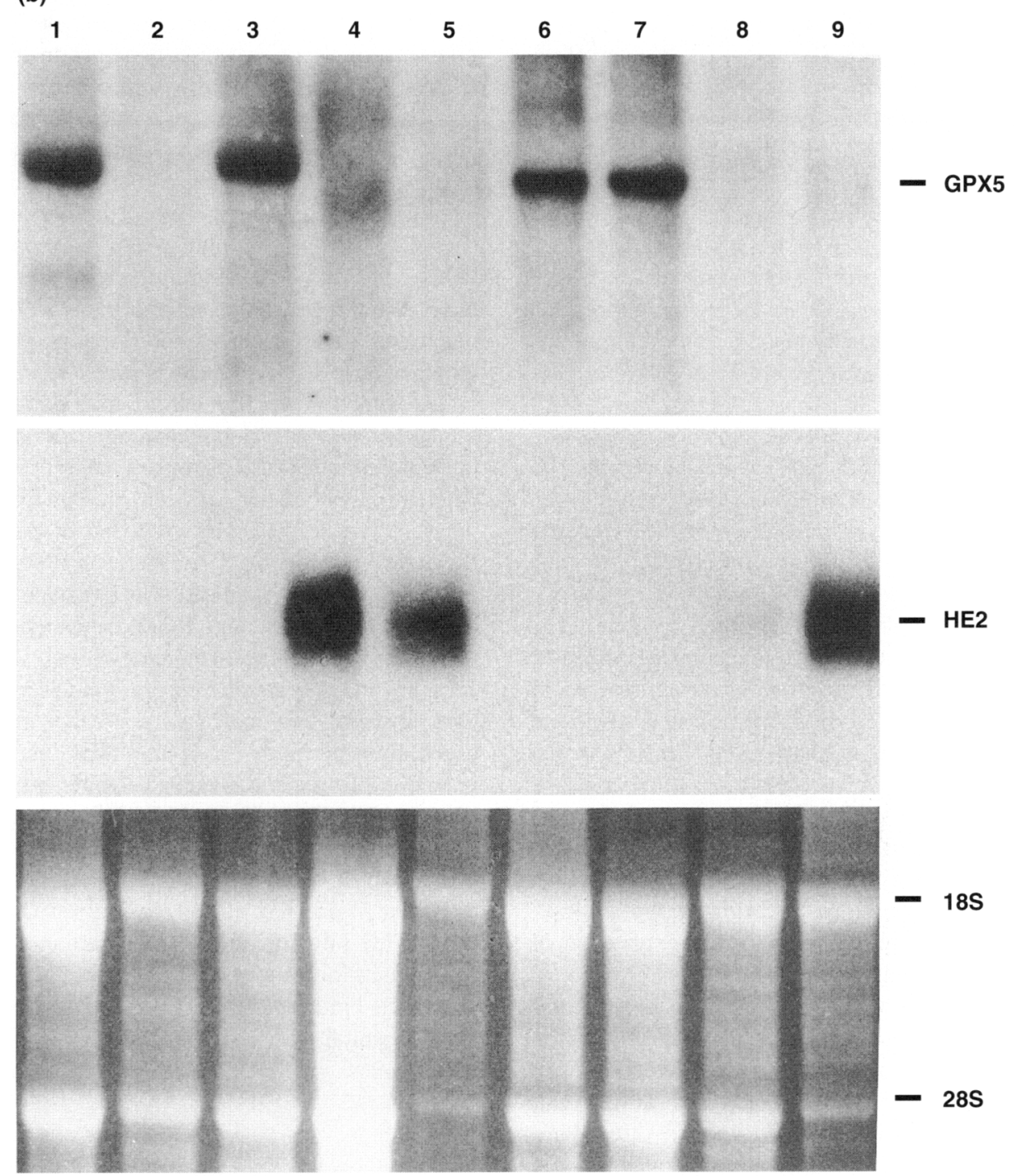

Fig. 5. Interspecies cross-hybridization of cDNA encoding CE7. (a) Northern blot carrying total RNA extracts of whole epididymides from seven species (mouse, boar, rat, dog, bull, stallion (Stal.) and man) was hybridized under non-stringent conditions with a ${ }^{32} \mathrm{P}$-labelled $650 \mathrm{bp}$ fragment of cDNA encoding CE7. RNA loading (approximately $10 \mu \mathrm{g}$ per lane) and integrity of ribosomal RNA ( $28 \mathrm{~S}$ and $18 \mathrm{~S}$ ) were checked by ethidium bromide staining of the gel before blotting (bottom panel, showing partial degradation of human epididymal RNA). (b) Northern blot (carrying various amounts of total and poly(A)-enriched RNA from either whole epididymides or isolated segments) was hybridized subsequently with a ${ }^{32} \mathrm{P}$-labelled $650 \mathrm{bp}$ fragment of cDNA encoding CE7 (upper panel) and a $700 \mathrm{bp}$ fragment of cDNA encoding HE2 (second panel). The integrity of ribosomal RNA ( $28 \mathrm{~S}$ and $18 \mathrm{~S}$ ) was ascertained by ethidium bromide staining of the gel before blotting (bottom panel). Lane 1: pooled mouse epididymides, $20 \mu \mathrm{g}$ total RNA; lane 2: marmoset epididymis, $10 \mu \mathrm{g}$ total RNA; lane 3; bovine caput epididymidis, $20 \mu \mathrm{g}$ total RNA; lane 4: human epididymis, $30 \mu \mathrm{g}$ total RNA; lane 5: human caput epididymidis, $5 \mu \mathrm{g}$ total RNA; lane 6: pig caput epididymidis, $20 \mu \mathrm{g}$ total RNA; lane 7: dog epididymis, $20 \mu \mathrm{g}$ total RNA; lane 8: human cauda epididymidis, $10 \mu \mathrm{g}$ total RNA; lane 9: human epididymis, $5 \mu \mathrm{g}$ poly (A)-enriched RNA.

sequence homologies ( $>80 \%$ nucleotide identity) with the cDNAs encoding GPX5 that had already been cloned from mice (Ghyselinck et al., 1993), rats and monkeys (Perry et al., 1992), (2) the N-terminal 21 amino acids fit the characteristics of a cleavable signal peptide charateristic for secretory proteins, and (3) no in-frame opal codon was present in the open reading frame. However, homology searches against the GenBank database revealed also high, albeit less extensive, similarity with the extracellular GPX3 and a rat odorant-metabolizing protein (Dear et al., 1991).

Differential screening and northern analyses revealed a highly restricted expression pattern for CE7/GPX5: the mRNA 
encoding it was only observed in the epididymis and not in other dog tissues. This restricted tissue distribution is in good agreement with that of the mRNA encoding GPX5 in other mammals (Faure et al., 1991; Perry et al., 1992), but is different from that of the other glutathione peroxidases (Maser et al, 1994; Pushpa-Rekha et al., 1995). In particular, the related mRNA encoding plasma GPX3 shows a very broad expression and is found in many tissues. The mouse epididymis, besides expressing the mRNA encoding GPX5, has also been shown to be a major site of expression of mRNA encoding plasma GPX3 (Maser et al., 1994; Schwaab et al., 1995). However, expression of mRNA encoding GPX3 is equally strong in the lung, testis and ovary (Maser et al., 1994) which were all negative for the mRNA encoding CE7/GPX5.

Expression of mRNA encoding CE7 along the dog epididymal duct was in accordance with that observed for mRNA encoding GPX5 in other species (Faure et al., 1991; Syntin et al., 1996; Vernet et al., 1997), the vast majority being expressed in the caput region. The interspecies conservation of this regionalized expression suggests that a conserved regulatory transcriptional mechanism may be involved. Moreover, the characteristic 'mottled' or 'checkerboard' expression pattern of the mRNA encoding CE7/GPX5 observed in certain regions of the dog corpus epididymidis is indicative of unknown and more complex cell-autonomous regulatory mechanisms in the epididymis.

GPX5 expression in the mouse epididymis was shown to be androgen-dependent (Ghyselinck et al., 1993). Moreover, nonsteroidal testicular factors may be involved (Rigaudière et al., 1992). Therefore, the hemi-cryptorchid condition was investigated to define factors that might regulate the expression of the mRNA encoding CE7/GPX5. This pathology offers a means by which the additive (or synergistic) effects of testicular factors and temperature on epididymis-specific gene expression may be evaluated (Uhlenbruck et al., 1993). The abdominal location of the testis is known to cause a reduction of testicular secretion, including that of androgens. Moreover, direct temperature effects on the dog epididymis have also been described (Pera et al., 1996). The present study revealed a differential response of specific mRNA concentrations to this pathology, depending on the epididymal region investigated, that is, not only did the mRNAs exhibit a regionalized expression pattern, but the modulation of mRNA concentrations by the factors mentioned seemed also to be regiondependent. The abdominal location markedly reduced the caput concentrations of mRNA encoding CE7/GPX5, but barely affected its distal expression pattern. A similar result was also observed for mRNAs encoding CEI and CE4. Only the temperature-sensitive mRNA encoding CE5/CD52 (compare with Pera et al., 1996) showed a reduction in the distal parts of the abdominal epididymis. We speculate that the downregulation of concentrations of mRNA encoding CE7/GPX5 in the abdominal caput was caused by a reduction of testicular secretions rather than by direct temperature effects on the epididymis. However, it was not possible to differentiate clearly between these factors.

No primate GPX5 counterparts were observed in the present study, although its occurrence is well documented in another primate, the cynomolgous monkey Macaca fascicularis (Perry et al., 1992). This could mean either that in our study the expected corresponding human and marmoset epididymal mRNAs were significantly less frequent as compared with other mammals, or that their gene products were too divergent to cross-hybridize with the heterologous dog probe. Considering the high sequence conservation among the known GPX5 homologues, including the cynomolgous monkey cDNA (Perry et al., 1992), this last possibility appears unlikely. Rather, quantitative differences between the concentrations of mRNA encoding GPX5 in the human and marmoset tissue samples on the one hand, and the epididymides of the other species on the other hand appeared to offer a plausible explanation for our negative results. However, additional work is required to reveal whether our negative result is physiologically significant.

The function of the epididymal secretory GPX5 in vivo remains unknown. Mammalian spermatozoa are rich in polyunsaturated fatty acids, a property that predisposes them to the deleterious effects of oxygen free radicals. Although lipid peroxidation seems to be involved in sperm capacitation and the acrosome reaction (Griveau et al., 1995, Aitken et al., 1996), it has also been implicated in increased sperm membrane fragility, anatomical and functional sperm abnormalities and impaired male fertility (for review see Aitken, 1995). In most cells, including spermatozoa, the intracellular concentrations of toxic oxygen free radicals seem to be regulated by various glutathione peroxidase activities that seem to involve selenoproteins (Alvarez and Storey, 1989; for review see Irvine, 1996; Storey, 1997). However, whether this intracellular GPX activity of spermatozoa can make a profound contribution to the protection of the sperm membrane during epididymal storage is unclear. Vernet et al. (1996) suggest that the mouse GPX5 protein, despite the absence of selenium, would function as a true glutathione peroxidase. Moreover, the protein has been shown to bind to spermatozoa and to be transported up the female genital tract (Vernet et al., 1997). Thus, a more direct involvement of GPX5 in the fertilization process is also possible.

The authors thank the local veterinary surgeons who are supporting this project with their time and enthusiasm. They are grateful to $\mathrm{M}$. Balvers for performing the in situ hybridization, and to several colleagues, in particular A. Einspanier, Göttingen, and R. Ivell, F. Uhlenbruck, and W. Rust, all from Hamburg, for provision of RNA and tissue samples. Special thanks are due to $F$. Leidenberger, Hamburg, for provision of excellent research facilities.

\section{References}

Aitken RJ (1995) Free radicals, lipid peroxidation, and sperm function Reproduction, Fertility and Development 7 659-668

Aitken RJ, Buckingham DW, Harkiss D, Paterson M, Fisher $\mathbf{H}$ and Irvine DS (1996) The extragenomic action of progesterone on human spermatozoa is influenced by redox regulated changes in tyrosine phosphorylation during capacitation Molecular and Cellular Endocrinology $11783-93$

Alvarez JG and Storey B'T (1989) Role of glutathione peroxidase in protecting mammalian spermatozoa from loss of motility caused by spontaneous lipid peroxidation Gamete Research 23 77-90

Chu FF (1994) The human glutathione peroxidase genes GPX2, GPX3, and $\mathrm{GPX}_{4}$ map to chromosomes 14,5 , and 19 , respectively Cytogenetics and Cell Genetics 66 96-98

Dear TN, Campbell K and Rabbitts TH (1991) Molecular cloning of putative odorant-binding and odorant-metabolizing proteins Biochemistry 3010376 10382 
Ellerbrock K, Pera I, Hartung S and Ivell R (1994) Gene expression in the dog epididymis: a model for human epididymal function International Journal of Andrology 17 314-323

Faure J, Ghyselinck NB, Jiminez C and Dufaure JP (1991) Specific distribution of messenger ribonucleic acids for 24 -kilodalton proteins in the mouse epididymis as revealed by in situ hybridization: developmental expression and regulation in the adult Biology of Reproduction 44 13-22

Ghyselinck NB, Jiminez C and Dufaure JP (1991) Sequence homology of androgen-regulated epididymal proteins with glutathione peroxidase in mice Journal of Reproduction and Fertility 93 461-466

Ghyselinck NB, Dufaure I, Lareyre J-J, Rigaudiere N, Mattei M-G and Dufaure J-P (1993) Structural organization and regulation of the gene for the androgendependent glutathione peroxidase-like protein specific to the mouse epididymis Molecular Endocrinology $7258-272$

Griveau JF, Renard P and Le-Lannou D (1995) Superoxide anion production by human spermatozoa as a part of the ionophore-induced acrosome reaction process International Journal of Andrology 18 67-74

Irvine DS (1996) Glutathione as a treatment for male infertility Reviews of Reproduction 16-12

Kirchhoff C, Osterhoff C, Habben I and Ivell R (1990) Cloning and analysis of mRNAs specifically expressed in the human epididymis International Joumal of Andrology $13 \quad 155-167$

Kirchhoff C, Habben I, Ivell R and Krull N (1991) A major human epididymisspecific CDNA encodes a protein with sequence homology to extracellular proteinase inhibitors Biology of Reproduction 45 350-357

Kirchhoff C, Krull N, Pera I and Ivell R (1993) A major mRNA of the human epididymal principal cells, HE5, encodes the leucocyte differentiation CDw52 antigen peptide backbone Molecular Reproduction and Development 34 $8-15$

Kirchhoff C, Pera I, Rust W and Ivell R (1994) A major human epididymisspecific gene product, HE3, is the first representative of a novel gene family Molecular Reproduction and Development 37 130-137

Maguire SM, Millar MR, Sharpe RM and Saunders PTK (1993) Stage-dependent expression of mRNA for cyclic protein 2 during spermatogenesis is modulated by elongated spermatids Molecular and Cellular Endocrinology 94 $79-88$

Maser RL, Magenheimer BS and Calvet JP (1994) Mouse plasma glutathione peroxidase Journal of Biological Chemistry 26927 066-27073

Osterhoff C, Kirchhoff C, Krull N and Ivell R (1994) Molecular cloning and characterization of a novel human sperm antigen (HE2) specifically expressed in the proximal epididymis Biology of Reproduction 50 516-525

Osterhoff C, Ivell R and Kirchhoff C (1997) Cloning of a human epididymisspecific mRNA, HE6, encoding a novel member of the seven transmembrane-domain receptor superfamily DNA and Cell Biology 16 379-389

Pera l, Ivell R and Kirchhoff C (1994) Regional variation of gene expression in the dog epididymis as revealed by in situ transcript hybridization International Journal of Andrology 17 324-330

Pera I, Ivell R and Kirchhoff C (1996) Body temperature $\left(37^{\circ} \mathrm{C}\right)$ specifically down-regulates the messenger ribonucleic acid for the major sperm surface antigen CD52 in epididymal cell culture Endocrinology 137 4451-4459

Perry AC, Jones R, Niang LS, Jackson RM and Hall L (1992) Genetic evidence for an androgen-regulated epididymal secretory glutathione peroxidase whose transcript does not contain a selenocysteine codon Biochemical journal 285 863-870

Pushpa-Rekha TR, Burdsall AL, Oleksa LM, Chisolm GM and Driscoll DM (1995) Rat phospholipid-hydroperoxide glutathione peroxidase Journal of Biological Chemistry 270 $26993-26999$

Rigaudière N, Ghyselinck NB, Faure J and Dufaure JP (1992) Regulation of the epididymal glutathione peroxidase-like protein in the mouse: dependence upon androgens and testicular factors Molecular and Cellular Endocrinology 89 $67-77$

Roveri A, Maiorino M and Ursini F (1994) Enzymatic and immunological measurements of soluble and membrane-bound phospholipid-hydroperoxide glutathione peroxidase Methods in Enzymology 233 202-212

Schwaab V, Baud E, Ghyselinck NB, Mattei MG, Dufaure JP and Drevet JR (1995) Cloning of the mouse gene encoding plasma glutathione peroxidase: organization, sequence, and chromosomal localization Gene 167 25-31

Storey BT (1997) Biochemistry of the induction and prevention of lipoperoxidative damage in human spermatozoa Molecular Human Reproduction 3 203-213

Syntin P, Dacheux F, Druart X, Gatti JL, Okamura N and Dacheux J-L (1996) Characterization and identification of proteins secreted in the various regions of the adult boar epididymis Biology of Reproduction 55 956-974

Uhlenbruck F, Sinowatz F, Amselgruber W, Kirchhoff C and Ivell R (1993) Tissue-specific gene expression as an indicator of epididymis-specific functional status in the boar, bull and stallion International Journal of Andrology 16 $53-61$

Vernet P, Rigaudiere N, Ghyselinck NB, Dufaure J-P and Drevet JR (1996) In vitro expression of a mouse tissue-specific glutathione peroxidase lacking the selenocysteine can protect stably transfected mammalian cells against oxidative damage Biochemistry and Cell Biology 74 125-131

Vernet P, Faure J, Dufaure J-P and Drevet JR (1997) Tissue and developmental distribution, dependence upon testicular factors and attachment to spermatozoa of GPX5, a murine epididymis-specific glutathione peroxidase Molecular Reproduction and Development 47 87-98 